\title{
Effect of the Anesthetic Method on the Outcomes of Ureteroscopy for Proximal Ureteral Stones: A Multi-center Study of the Society of Urological Surgery Aegean Study Group
}

\author{
Proksimal Üreter Taşı Nedeniyle Üreteroskopi Uygulanan Hastalarda Anestezi Yönteminin \\ Sonuçlara Etkisi: Ürolojik Cerrahi Derneği Ege Çalışma Grubu'nun Çok Merkezli Bir Çalışması
} \author{
(1) Mehmet Şahin1, (1) Mehmet Oğuz Şahin ${ }^{3}$, (1) Ahmet Cihan ${ }^{8}$, (1) 0ktay Üçer ${ }^{4}$, (1) Ozan Bozkurt6 \\ 1 Ege University Faculty of Medicine, Department of Urology, Izmir, Turkiye \\ 2 İzmir Metropolitan Municipality Eşrefpaşa Hospital, Clinic of Urology, İzmir, Turkiye \\ 3 Manisa State Hospital, Clinic of Urology, Manisa, Turkiye \\ ${ }^{4}$ Manisa Celal Bayar University Faculty of Medicine, Department of Urology, Manisa, Turkiye \\ 5istanbul Bahçelievler State Hospital, Clinic of Urology, Istanbul, Turkiye \\ ${ }^{6}$ Dokuz Eylül University Faculty of Medicine, Department of Urology, İzmir, Turkiye \\ ${ }^{7}$ Bülent Ecevit University Faculty of Medicine, Department of Urology, Zonguldak, Turkiye \\ ${ }^{8}$ Niğde Ömer Halisdemir University Faculty of Medicine, Department of Urology, Niğde, Turkiye
}

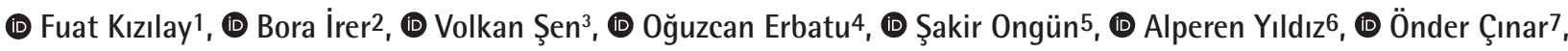

\section{What's known on the subject? and What does the study add?}

Ureteroscopy is an effective method for the treatment of proximal ureteral stones and provides high stone-free rates. Many factors affecting the success of ureteroscopy have been discussed extensively in the literature. The anesthetic method considered to be one of these factors is also discussed, but mostly general and spinal anesthesia were compared with local anesthesia. The purpose of this study was to compare the impact of spinal and general anesthesia on ureteroscopy performed for the treatment of proximal ureter stones and it concluded that both methods are safe and effective.

\begin{abstract}
Objective: To analyze the effect of the anesthesia method (spinal and general) on the outcome of ureteroscopy (URS) in patients treated for proximal ureteral stones.

Materials and Methods: Patients, who underwent URS for proximal ureteral stones at various urology clinics in Turkiye, were included in the study. The patients were divided into two groups according to the anesthesia method performed; the procedure was performed under spinal anesthesia $(\mathrm{SA})$ in group 1 and general anesthesia (GA) in group 2. Patients' demographic, perioperative data and complication rates were compared between the two groups in a retrospective manner.

Results: There were 309 and 329 patients in groups 1 and 2, respectively. The mean stone area and Hounsfield unit in GA group were higher ( $<<0.001$ and $p=0.007$, respectively). In the GA group, the need for double J stent was more frequent $(p<0.001)$. In the SA group, the rate of push-back of stone into the collecting system was higher $(p=0.017)$. According to the Clavien classification system and the others, complication rates were similar between the two groups ( $p>0.05$ ). The rate of success of URS, which is accepted as complete stone-free status, was higher in the SA group ( $p=0.041$ ). Conclusion: URS, which is used in the treatment of proximal ureteral stones, has a high success rate, independent of the anesthesia method used. It is important to keep in mind the patient's comorbidities prior to selecting the anesthesia method and that the stone area and the Hounsfield unit are the important factors affecting the outcomes.
\end{abstract}

Keywords: Ureteroscopy, Ureteral stone, Spinal anesthesia, General anesthesia, Complication

Correspondence: Fuat Kızılay MD, Ege University Faculty of Medicine, Department of Urology, İzmir, Turkiye

Phone: +90 5325800685 E-mail: fuatkizilay@gmail.com ORCID-ID: orcid.org/0000-0003-1856-0404

Received: 08.06.2018 Accepted: 27.07.2018

Cite this article as: Kızılay F, İrer B, Şen V, Erbatu O, Ongün Ş, Yıldız A, Çınar Ö, Şahin M, Şahin MO, Cihan A, Üçer O, Bozkurt O. Effect of the Anesthetic Method on the Outcomes of Ureteroscopy for Proximal Ureteral Stones: A Multi-center Study of the Society of Urological Surgery Aegean Study Group. J Urol Surg 2018;5(4):170-175.

๑Copyright 2018 by the Association of Urological Surgery / Journal of Urological Surgery published by Galenos Publishing House. 


\section{Öz}

Amaç: Bu çalışmada, anestezi yönteminin (spinal ve genel) proksimal üreter taşı tedavisinde uygulanan üreteroskopi (URS) sonuçlarına etkisini değerlendirdik.

Gereç ve Yöntem: Türkiye'deki farklı üroloji kliniklerinde proksimal üreter taşı nedeniyle URS uygulanan hastalar, çalışmaya dahil edildi. Hastalar, uygulanan anestezi yöntemine göre spinal anestezi (SA) uygulanan birinci grup ve genel anestezi (GA) uygulanan ikinci grup olmak üzere iki gruba ayrıldı. İki grup arasında, hastaların demografik ve perioperatif verileri ve komplikasyon oranları retrospektif olarak karşılaştırıldı.

Bulgular: Birinci grupta 309 hasta, ikinci grupta 329 hasta vardı. GA grubunun ortalama taş alanı ve Hounsfield ünitesi daha yüksekti (sırasıyla, $p<0,001$ ve $p=0,007)$. GA grubunda, double J stent gereksinimi daha fazlaydı $(p<0,001)$. SA grubunda, taşın toplayıcı sisteme "push-back" oranı daha fazlaydı ( $p=0,017)$. Genel ve Clavien sınıflandırma sistemine göre, komplikasyon oranları iki grup arasında benzerdi ( $>00,05)$. Tam taşsızlık olarak kabul edilen URS'nin başarı oranı, SA grubunda daha fazlaydı $(p=0,041)$.

Sonuç: Proksimal üreter taşlarının tedavisinde kullanılan URS, kullanılan anestezi yönteminden bağımsız, yüksek başarı oranlarına sahip bir yöntemdir. Anestezi yönteminin seçiminde hastanın komorbiditelerini göz önünde bulundurmak ve taş alanı ve Hounsfield ünitesinin sonuçları etkileyen önemli faktörler olduğunu akılda tutmak gerekir.

Anahtar Kelimeler: Üreteroskopi, Üreter taşı, Spinal anestezi, Genel anestezi, Komplikasyon

\section{Introduction}

Urinary system stone disease is a common problem and its prevalence may be up to $20 \%$ with geographical, climatic, ethnic, dietary and genetic factors (1). Urinary stones can be classified according to their etiology, composition, risk of recurrence, $\mathrm{X}$-ray features, size and location (2).

Important factors determining spontaneous stone passage are the size and location of the stone (3). While the spontaneous passage rate for stones smaller than $5 \mathrm{~mm}$ is high, this rate for larger stones is dramatically decreased; the rate is very low for stones over $10 \mathrm{~mm}$. Proximal ureteral stones are less likely to pass spontaneously compared to those in other locations. The spontaneous passage rate for proximal ureteral stones is generally $48 \%$, which is $79 \%$ for stones in the ureterovesical junction (4). Stones with a low chance of spontaneous passage, persistent pain despite adequate analgesic treatment, persistent obstruction and renal insufficiency constitute the indications for active ureteral stone removal (5). Currently, treatment options for ureteral stones are observation, medical expulsive therapy, shock wave lithotripsy (SWL), ureteroscopy (URS), percutaneous nephrolithotomy, laparoscopic surgery, and open surgery (6).

The stone-free rate (SFR) in URS and SWL, which are two commonly used treatment methods for ureteral stones, is similar. However, better rates can be obtained with URS in larger stones. With the advances in technical equipment, the formerly high complication rate has decreased significantly for URS (7). It has also been possible to achieve high SFRs with URS in proximal ureteral stones, and the current European Association of Urology (EAU) urolithiasis guideline recommend URS (anteor retro-grade) as the first treatment option in stones larger than $10 \mathrm{~mm}$, and SWL or URS in stones smaller than $10 \mathrm{~mm}$, evenly (6). This suggestion was SWL as the first option for stones smaller than $10 \mathrm{~mm}$ and URS or SWL for stones larger than $10 \mathrm{~mm}$ in the previous guidelines (8). Undoubtedly, the effect of dazzling technical and technological progress in the field of endourology on this dramatic change is great.

In the literature, many factors affecting the success of URS have been evaluated. Technical equipment (endoscope type, ureteroscope type, fragmentation method, etc.), pre-stenting, stone size and location are the most commonly discussed factors. The effect of anesthesia method which is applied during the procedure is controversial. In the EAU guideline, it is stated that most procedures are performed under general anesthesia (GA), but local or spinal anesthesia (SA) is also possible. Intravenous sedation is also suitable for female patients with distal ureteral stones (9). In this multi-center study, we aimed to analyze the impact of anesthesia method (SA and GA) on the outcome of the patients treated with endoscopic ureteral stone treatment due to proximal ureteral stone.

\section{Materials and Methods}

\section{Patients and Data Collection}

Data of patients, who underwent URS due to proximal ureteral stones in different reference centers, were obtained from patient files. A total of 638 patients underwent ureteroscopic lithotripsy. Patients were divided into two groups according to the anesthesia method: group SA ( $n=309)$ and group $G A(n=329)$. The anesthesia method was determined by the anesthesiologists of the relevant clinics. Anesthesiologists performed SA or GA according to their clinical and patient preferences. Stones located in the region between the ureteropelvic junction and the pelvic brim in the ureter were considered proximal stones and included in the study. The stones that were immobilized, embedded in the ureteric mucosa, and those with mucosal fold observed during endoscopic visualization were evaluated as impacted stones. URS was considered successful upon determination stone-free status with the imaging methods after treatment. All patients 
were evaluated post-operatively by non-contrast computed tomography or abdominal radiography. The stone area was calculated in square millimeters by multiplying the longest two dimensions. Patients' perioperative double J stent requirement, gender, stone push-back status, general complication rate and Clavien classification and URS success rate (stone-free) data were collected. The relationship between the anesthesia method (SA or GA) and these variables were evaluated. Ethics Committee of Dokuz Eylül University has approved this study (approval number 2018/03-03). Written informed consent was not obtained from patients because this was a retrospective study. The principles of the Helsinki Declaration were followed during the study, and the confidentiality of the patients' data was guaranteed.

\section{Surgical Technique}

Sterile urine culture was provided prior to the procedure. $1 \mathrm{~g}$ intravenous cefazolin was administered following SA or GA. In the lithotomy position, 5\% lidocaine gel was applied to the urethra. All the procedures were performed using semirigid or rigid ureteroscopes with 8 or $9 \mathrm{Fr}$ distal tip. A guidewire with 3 $\mathrm{cm}$ flexible tip was used routinely to guide ureteroscope. If stone access achieved, a holmium laser or a pneumatic lithotripter was used for stone fragmentation. A 16 or 18 Fr Foley catheter was introduced into the bladder with the completion of the operation and was taken on the same day or one day later.

\section{Statistical Analysis}

Pearson's chi-square test was used to compare the difference in the anesthesia method between the two groups. If the smallest theoretical frequency was $<5$, Fisher's exact test was used to analyze the variables. An independent-samples t-test was conducted to compare outcomes for URS in SA and GA conditions. Data were analyzed using the SPSS (version 23.0) statistical program. A $p$ value of less than 0.05 was considered statistically significant.

\section{Results}

The vast majority of patients were male ( $n=424,66.5 \%$ vs $33.5 \%$ ). Four hundred and thirty patients (67.4\%) had no systemic disease. Approximately one third of the patients $(n=188$, 29.5\%) had a chronic medication use. Approximately half of the patients had a history of stone disease $(n=304,47.6 \%)$, but SWL history was absent in the vast majority of the patients $(n=455$, $71.3 \%$ ). $84.6 \%$ of the patients $(n=540$ ) had no previous history of stone surgery. There was no significant difference in terms of energy source used to fragment the stone (laser: $50.8 \%$ vs pneumatic: $49.2 \%$ ) and side of the stone (right: $50.8 \%$ vs left: 49.2\%). 51.6\% $(n=329)$ of the patients were operated with GA and $48.4 \%(n=309)$ with SA. The majority of the stones were not impacted ( $n=491,77 \%)$. The great majority of patients required perioperative double-J stenting $(n=396,62.1 \%)$. Of the 638 patients whose data were evaluated, 527 (82.6\%) had no residual stone after the procedure. The stones were "pushedback" to the renal collecting system during the procedure in 15 $(2.4 \%)$ patients. The overall complication rate was $11 \%(n=70)$. According to the Clavien classification, 586 patients (91.8\%) had no complication, 36 patients (5.6\%) had Clavien grade 1, 6 patients $(0.9 \%)$ had grade 2 , and 5 patients $(0.8 \%)$ had grade 3 and 4 complications. The most common complication was postoperative fever in 24 patients (3.8\%). Following that, lumbar pain $(n=11,1.7 \%)$, urosepsis $(n=5,0.8 \%)$, ureteral perforation $(n=5,0.8 \%)$, urinary tract infection $(n=5,0.8 \%)$, post-operative hematuria $(n=1,0.2 \%)$, and arrhythmia $(n=1,0.2 \%)$ were the most common complications, respectively. URS success rate was 82.6\% ( $n=527)$. Demographic data and stone characteristics of the patients are summarized in Table 1.

In the SA group, stone area and the Hounsfield unit of the stone on computed tomography was significantly lower than in the GA group ( $p<0.001$ and $p=0.007$, respectively). There was no statistically significant difference in the other variables between the groups $(p>0.05)$. The relationship of demographic data and stone characteristics with the anesthesia method is summarized in Table 2.

Table 1. Demographic data and stone characteristics of the patients

\begin{tabular}{lll}
\hline & Mean & Range \\
\hline Age (years) & $44.9 \pm 14.4$ & $15-87$ \\
BMI $\left(\mathrm{kg} / \mathrm{m}^{2}\right)$ & $26.2 \pm 3.6$ & $17.3-39.6$ \\
Stone area $\left(\mathrm{mm}^{2}\right)$ & $83.7 \pm 57.2$ & $20-560$ \\
Hounsfield unit & $883.7 \pm 380.3$ & $240-3200$ \\
Operation time (minute) & $45.1 \pm 19.1$ & $10-135$ \\
Length of stay (day) & $1.8 \pm 2.0$ & $1-23$ \\
\hline BMI: Body mass index & & \\
\hline
\end{tabular}

Table 2. Relationship of demographic data and stone characteristics with the anesthesia method

\begin{tabular}{llll}
\hline & $\begin{array}{l}\text { Spinal } \\
\mathbf{n = 3 0 9}\end{array}$ & $\begin{array}{l}\text { General } \\
\mathbf{n = 3 2 9}\end{array}$ & p value \\
\hline Age (years) & $45.0 \pm 14.1$ & $44.7 \pm 14.7$ & 0.790 \\
BMI $\left(\mathrm{kg} / \mathrm{m}^{2}\right)$ & $26.3 \pm 3.5$ & $26.2 \pm 3.7$ & 0.711 \\
Stone area $\left(\mathrm{mm}^{2}\right)$ & $73.9 \pm 38.4$ & $92.9 \pm 69.2$ & $<0.001$ \\
Hounsfield unit & $829.3 \pm 346.1$ & $933.3 \pm 403.5$ & 0.007 \\
Operation time (minute) & $44.2 \pm 20.4$ & $46.0 \pm 17.8$ & 0.240 \\
Length of stay (day) & $1.8 \pm 1.6$ & $1.8 \pm 2.3$ & 0.834 \\
\hline BMI: Body mass index & & & \\
\hline
\end{tabular}


The need for a double J stent was significantly higher in the GA group than in the SA group ( $83.3 \%$ vs $39.5 \%, p<0.001$ ). The rate of push-back to the collecting system was higher in the SA group ( 3.9 vs $0.9 \%, p=0.011$ ). The general complication rate was slightly higher in the SA group, but not statistically significant ( $8.7 \%$ vs $7.6 \%, p=0.665)$. The rates of complications according to the Clavien classification were also similar between the two groups $(p=0.789)$. URS success rate, which we regarded as complete stone-free status, was higher in SA group (85.8\% vs $79.6 \%, p=0.041)$. The relationship of the variables with the anesthesia method is summarized in Table 3 .

\section{Discussion}

There is a tendency to perform URS with regional anesthesia for the diagnosis and treatment of upper urinary tract pathologies. However, this trend is present largely among anesthesiologists, because in this way, they aim to accelerate the turnover in the operating room and reliably discharge the patients on the same day with easier post-operative care. However, this situation is controversial from the urologist perspective. It is a strongly believed opinion that the movement of the patient in

\begin{tabular}{|c|c|c|c|}
\hline & $\begin{array}{l}\text { Spinal } \\
n=309\end{array}$ & $\begin{array}{l}\text { General } \\
n=329\end{array}$ & p value \\
\hline \multicolumn{4}{|c|}{ Double j stent } \\
\hline Yes & $122(39.5 \%)$ & $274(83.3 \%)$ & \multirow{2}{*}{$<0.001$} \\
\hline No & $187(60.5 \%)$ & $55(16.7 \%)$ & \\
\hline \multicolumn{4}{|c|}{$\begin{array}{l}\text { Push-back to the } \\
\text { collecting system }\end{array}$} \\
\hline Yes & $12(3.9 \%)$ & $3(0.9 \%)$ & \multirow{2}{*}{0.011} \\
\hline No & $297(96.1 \%)$ & $326(99.1 \%)$ & \\
\hline \multicolumn{4}{|l|}{ Complication } \\
\hline Yes & $27(8.7 \%)$ & $25(7.6 \%)$ & \multirow{2}{*}{0.665} \\
\hline No & $282(91.3 \%)$ & $304(92.4 \%)$ & \\
\hline \multicolumn{4}{|c|}{ Clavien classification } \\
\hline Clavien 1 & $20(6.5 \%)$ & $16(4.9 \%)$ & \multirow{5}{*}{0.789} \\
\hline Clavien 2 & $2(0.6 \%)$ & $4(1.2 \%)$ & \\
\hline Clavien 3 & $3(1.0 \%)$ & $2(0.6 \%)$ & \\
\hline Clavien 4 & $2(0.6 \%)$ & $3(0.9 \%)$ & \\
\hline No & $282(91.3 \%)$ & $304(92.4 \%)$ & \\
\hline \multicolumn{4}{|c|}{$\begin{array}{l}\text { Ureteroscopy success } \\
\text { rate }\end{array}$} \\
\hline Successful & 265 (85.8\%) & 262 (79.6\%) & \multirow{2}{*}{0.041} \\
\hline Unsuccessful & $44(14.2 \%)$ & $67(20.4 \%)$ & \\
\hline
\end{tabular}

the cases of regional anesthesia may lead to ureteral trauma and that reflexes, such as deep breathing and cough, can be better controlled by GA. However, no significant difference was found in the literature in terms of ureteral trauma in URS with or without GA. There are many studies in the literature about the safety and tolerability of URS with local anesthesia and intravenous sedation $(10,11)$.

In a surgical procedure, the anesthesiologist and the surgeon have different objectives and expectations from the operation. While the surgeon expects to end the operation with minimal complications and the most successful outcomes, the anesthesiologist aims to awaken the patient in the safest and fastest manner, after surgery. These goals can conflict in a technical and specific operation like URS. Urologists believe that the proximal stones are more easily accessible under favour of more relaxation of the ureter with $\mathrm{GA}$, and that prevention of involuntary reflexes, such as coughing and sneezing, is more possible. The underlying reason for this belief is that there is a longer way to go for proximal ureteral stones with a rigid or semi-rigid ureteroscope and fragmentation is more susceptible to complications with a longer URS device remaining in the ureter.

There are many studies in the literature that compared the anesthesia methods used in URS $(10,11,12,13,14,15,16)$. However, most of these studies compared local anesthesia with SA and GA. In addition, the patients were carefully selected in most series (13). The patients were often female and stone location was mostly distal ureter. Less complicated stones were included and thinner caliber (6.9-7.5 Fr) ureteroscopes were used for the interventions.

Park et al. (17) evaluated the efficacy of URS and patient tolerability with local anesthesia and concluded that the procedure was effective and tolerable. However, only 6 of 200 stones were located in the upper ureter, and none were larger than $10 \mathrm{~mm}$. Al-Naimi et al. (18) evaluated URS results in 1182 patients who underwent URS under SA or GA in a training hospital. They did not indicate an exact number, but most patients underwent GA and they found that stone location and stone impaction were predictive factors for an adverse outcome. Hollenbeck et al. (19) evaluated the outcomes of URS in ureteral stones above and below the pelvic brim (proximal-distal). The number of applied anesthesia methods (GA, SA and sedation) was similar between the two groups. The authors concluded that ureteroscopic stone therapy can be safely applied in stones at the pelvic brim and that patients with proximal ureteral stones were not at greater risk.

Although there is no head-to-head comparison of the impact of SA and GA on URS outcomes in the above mentioned studies, indirectly, it is understood that the anesthesia method has no 
significant effect on the results. In our study, we found that the results of $\mathrm{SA}$, rather than $\mathrm{GA}$ as we suspected, were slightly better. In the present study, URS success rate was high similarly to the above mentioned studies in both groups $(85.8 \%$ in the SA group and $79.6 \%$ in the GA group). We also found that both methods could be performed safely and effectively with similar complication rates. Moreover, the rate of the double J stent implementation was significantly higher in the GA group, but we consider that the higher stone area and the Hounsfield unit of the stones in this group were the possible reasons for this outcome. In the SA group, the rate of push-back to the collecting system was higher (3.9\% vs $0.9 \%$ ). The fact that the stones in this group were smaller in area may be an important factor affecting this outcome. It would not be wrong to come to the conclusion that with $\mathrm{GA}$, the ureter is not more relaxed as it is supposed to be. More relaxed ureter may be a factor that makes the stone more mobile and facilitates the push-back of the stone.

Regional anesthesia may also have undesirable effects such as postspinal headache requiring hospitalization and prolonged urinary retention. Due to these negative effects of block anesthesia, there has been an increase in the choice of GA for endoscopic ureteral stone treatment in recent years. Undoubtedly, the risk of further complications in proximal ureteral stones contributes to this increase. The faster onset of SA and leading to a more localized and dense block than epidural anesthesia, make it a necessary option in some cases. SA is often the preferred method of anesthesia in pregnant patients, because the amount of drug that passes through the fetus is minimized. Sometimes, anesthesiologists prefer GA in patients with serious cardiovascular and respiratory comorbidities. In such cases, especially in those with proximal ureteral stones, when regional anesthesia is preferred, the block should be made high enough to cover the pain fibers of the kidneys at the level of T8. In addition, epidural anesthesia or GA may be preferred to $S A$ in patients with severe cardiac disease, where sudden hypotension must be prevented, because the block becomes fast and the level becomes fixed within a short time with SA. The settlement of the block may take 10-15 minutes with epidural anesthesia and sudden hemodynamic changes are less expected.

\section{Study Limitations}

Our study is not without limitations. First, this is a retrospective study. Complications of the anesthesia methods used are not available, and their inclusion may have a significant contribution to the comparison in terms of anesthesia. The present study is a multi-center study. For this reason, a complete standardization of surgical and anesthetic applications could not be achieved. However, the high number of cases, comparison of common results of multi-centers, and being the first study to compare the impact of anesthesia methods on URS for proximal ureteral stones in the literature, as well as providing data for routine daily practice are important aspects of the present study.

\section{Conclusion}

URS is a safe and effective treatment method for proximal ureteral stones, whether with $\mathrm{SA}$ or $\mathrm{GA}$, regardless of the anesthesia method used. The cardiovascular and respiratory comorbidities of the patient are more important factors for determining the anesthetic method. It should also be kept in mind that stone size and the Hounsfield unit are significant components affecting the outcome of the procedure.

\section{Acknowledgments}

The authors declare that they have no relevant financial interests and no conflicts of interest.

\section{Ethics}

Ethics Committee Approval: This study was approved by the Ethics Committee of Dokuz Eylül University with number 2018/03-03.

Informed Consent: Written informed consent was not obtained from patients because this was a retrospective study.

Peer-reviewed: Externally peer-reviewed.

\section{Authorship Contributions}

Surgical and Medical Practices: F.K., B.I.., V.Ş., O.E., Ş.O., A.Y., Ö.Ç., M.Ş., M.O.Ş., A.C., O.Ü., O.B., Concept: F.K., B.I.., V.Ş., M.O.Ş., 0.Ü., O.B., Design: F.K., B.İ., V.Ş., M.O.Ş., O.Ü., O.B., Data Collection or Processing: F.K., B.I., V.Ş., O.E., Ş.O., A.Y., Ö.Ç., M.Ş., M.O.Ş., A.C., O.Ü., O.B., Analysis or Interpretation: F.K., B.İ., Literature Search: F.K., Writing: F.K.

Conflict of Interest: No conflict of interest was declared by the authors.

Financial Disclosure: The authors declared that this study received no financial support

\section{References}

1. Trinchieri A. Epidemiological trends in urolithiasis: impact on our health care systems. Urol Res 2006;34:151-156.

2. Hesse $A$, Brandle $E$, Wilbert $D$, Köhrmann KU, Alken P. Study on the prevalence and incidence of urolithiasis in Germany comparing the years 1979 vs. 2000. Eur Urol 2003;44:709-713.

3. Parekattil SJ, Kumar U, Hegarty NJ, Williams C, Allen T, Teloken P, Leitao VA, Netto NR, Haber GP, Ballereau C, Villers A, Streem SB, White MD, Moran ME. External validation of outcome prediction model for ureteral/renal calculi. J Urol 2006;175:575-579.

4. Coll DM, Varanelli MJ, Smith RC. Relationship of spontaneous passage of ureteral calculi to stone size and location as revealed by unenhanced helical CT. AJR Am J Roentgenol 2002;178:101-103. 
5. Skolarikos A, Mitsogiannis $H$, Deliveliotis C. Indications, prediction of success and methods to improve outcome of shock wave lithotripsy of renal and upper ureteral calculi. Arch Ital Urol Androl 2010;82:56-63.

6. Zumstein V, Betschart P, Abt D, Schmid HP, Panje CM, Putora PM. Surgical management of urolithiasis - a systematic analysis of available guidelines. BMC Urol 2018;18:25.

7. Cui X, Ji F, Yan H, Ou TW, Jia CS, He XZ, Gao W, Wang Q, Cui B, Wu JT. Comparison between extracorporeal shock wave lithotripsy and ureteroscopic lithotripsy for treating large proximal ureteral stones: a meta-analysis. Urology 2015;85:748-756.

8. Türk C, Knoll T, Petrik A, Sarika K, Straub M, Seitz C. Guidelines on Urolithiasis (EAU). 2014.

9. Cybulski PA, Joo H, Honey RJ. Ureteroscopy: anesthetic considerations. Urol Clin North Am 2004;31:43-47.

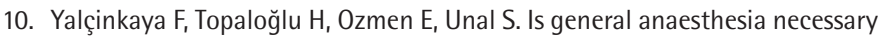
for URS in women? Int Urol Nephrol 1996;28:153-156.

11. Miroglu C, Saporta L. Transurethral ureteroscopy: is local anesthesia with intravenous sedation sufficiently effective and safe? Eur Urol 1997;31:3639.
12. Hosking DH, Smith WE, McColm SE. A comparison of extracorporeal shock wave lithotripsy and ureteroscopy under intravenous sedation for the management of distal ureteric calculi. Can J Urol 2003;10:1780-1784.

13. Rittenberg MH, Ellis DJ, Bagley DH. Ureteroscopy under local anesthesia. Urology 1987;30:475-478.

14. Chan PS, Fenn J, Li AK. Transurethral ureterorenoscopic lithotripsy and retrieval of ureteric calculi under local anaesthesia and sedation. Br J Urol 1990;65:141-143.

15. Grasso M, Bagley DH. Endoscopic pulsed-dye laser lithotripsy: 159 consecutive cases. J Endourol 1994;8:25-27.

16. Zisman A, Siegel $\mathrm{Y}$, Lindner A. Ureteroscopy for ureterolithiasis with sedation only. Eur Urol 1995;27:151-153.

17. Park HK, Paick SH, Oh SJ, Kim HH. Ureteroscopic lithotripsy under local anesthesia: analysis of the effectiveness and patient tolerability. Eur Urol 2004;45:670-673.

18. Al-Naimi A, Alobaidy A, Majzoub A, Ibrahim TA. Evaluation of ureteroscopy outcome in a teaching hospital. Turk J Urol 2016;42:155-161.

19. Hollenbeck BK, Schuster TG, Faerber GJ, Wolf JS Jr. Comparison of outcomes of ureteroscopy for ureteral calculi located above and below the pelvic brim. Urology 2001;58:351-356. 